\title{
Neoplasm Polygenic Risk Score
}

National Cancer Institute

\section{Source}

National Cancer Institute. Neoplasm Polygenic Risk Score. NCI Thesaurus. Code C158975.

A numeric value that estimates the risk of development of a specified neoplastic disease that is based on weighted regression analysis of disease-specific gene variants at multiple genetic loci. 